\title{
Pembuatan mesin uji tarik kapasitas kecil: bagian data akuisisi
}

Pandri Pandiatmi`, IDK Okariawan, Emmy Diah Sulistyowati, Salman, IG.A.K. Chatur Adhi

Teknik Mesin Fakultas Teknik Universitas Mataram, Jln. Majapahit No. 62 Mataram Nusa Tenggara

Barat Kode Pos : 83125, Telp. (0370) 636087; 636126; ext 128 Fax (0370) 636087.

*Email: pandri.pandiatmi@gmail.com

ARTICLE INFO

Article History:

Received 22 February 2017

Accepted 15 April 2017

Available online 30 June 2017

Keywords:

Tensile testing machine

Data acquisition

\section{ABSTRACT}

For the purposes of practicum and student research in the field of materials, tensile test equipment is very important. But the test equipment that is in the Department of Mechanical Engineering, University of Mataram has a very large capacity so it is not suitable for testing materials such as plastics and composites so this study bertujuann to make small capacity tensile testing machine for purposes of practicum and student research in the field of polymer materials and composites. Due to limited funds, the research is focused on making data acquisition tensile testing machine. Necessary materials are on site, cable, lead solder, lacquers cable socket and supported by laboratory equipment mechanical engineering majors who have been there, but some of the components to be purchased as load cell, electronic extensometer, and the operational amplifier module arduino uno boad. Design data acquisition consists of a sensor that is load cell, extensometer electronic, signal conditioning is an operational amplifier that is arduino uno data recording boad connected with the personal computer and data processing using LabView software so that the output of the data acquisition is in the form of tables and graphs. With their small capacity tensile testing machine is expected to provide an additional means of learning in the laboratory and student research.

\section{PENDAHULUAN}

Alat uji merupakan sarana laboratorium pendidikan yang sangat penting dalam menunjang dan mendukung proses belajar mengajar di laboratorium. Saat ini, pengembangan teknologi lebih banyak dititik beratkan dalam pengembangan material yang lebih ringan, dengan kekuatan yang tinggi dan memiliki ferformansi yang baik. Sehingga dalam pengembangan material tersebut memerlukan alat uji yang sesuai dengan sifat material yang diuji.

Saat ini, alat uji tarik yang dijual di pasaran mempunyai harga lebih dari $\mathrm{Rp} 50$ juta dan mempunyai berbagai jenis bentuk dan ukuran. Untuk mesin uji tarik kapasitas kecil yang banyak tersedia adalah mesin uji single column. Karena kebutuhan, mesin uji tarik yang didesain juga dapat langsung dimasukkan ke dalam mikroskop untuk menguji proses deformasi dan beban- 
elongasi secara bersamaan (Dean et al., 2014). Untuk plat-plat tipis dengan spesimen sangat kecil juga dapat didesain dengan menggunakan penggerak motos stepper dan grip penarik tunggal (Lim and Kim, 2013).

Kerangka alat uji tarik biasanya terbuat dari baja, karena baja mempunyai modulus elastisitas yang tinggi sekitar $200 \mathrm{GPa}$ dan juga kekuatan tarik tinggi, sekitar $600 \mathrm{MPa}$ (Callister, 2007). Hal ini memungkin untuk menggunakan dimensi yang kecil namun tetap kuat mendukung beban selama proses pembebanan.

Seperti halnya mesin uji tarik mini untuk edukasi (Lim and Kim, 2013) pencatatan data yang diperlukan pada mesin ini adalah gaya tarik $(F)$ dan perpanjangan $(\Delta \mathrm{L})$ secara bersamaan, kemudian data tersebut harus diformulasi menjadi tegangan dan regangan. Keluaran dari uji tarik ini adalah berupa tabel gaya tarik $(F)$, perpanjangan $(\Delta \mathrm{L})$, tegangan, regangan dan grafik teganganregangan. Untuk mencapai hal tersebut dibutuhkan sistem pencatatan data dengan bantuan sistem komputer yang terintegrasi. Metode untuk mencatat data gaya tarik (F) dilakukann dengan mensensing langsung menggunakan load cells dan mengkonversi tekanan hidrolik ke gaya tarik.

Tujuan penelitian ini adalah untuk mendesain dan membuat alat uji tarik tarik dengan kapasitas kecil yang mampu mendukung kebutuhan praktikum mahasiswa, terutama untuk pengujian material plastic dan komposit. Komponen alat uji yang akan didesain meliputi kerangka alat uji, system hidrolik untuk penarikan specimen dan data akuisisi.

\section{METODE PENELITIAN}

Metode yang digunakan dalam penelitian ini adalah perancangan dan juga pembuatan mesin uji tarik, yang dapat digunakan untuk pembebanan tarik dan tekan sekaligus beban bending. Dimana, pembuatan secara lengkap mesin uji tarik dikerjakan perbagian yang terdiri dari 3 bagian dan oleh 3 tim yang berbeda. Bagian pertama, kedua dan ketiga masing-masing adalah kerangka mesin, bagian penggerak serta grip spesimen dan data akuisisi. Dalam penelitian ini mengerjakan bagian yang ketiga yaitu data akuisisi. Gambar 1 berikut menunjukkan skematika dari perancangan sistem yang diusulkan.

\section{HASIL DAN PEMBAHASAN \\ Perancangan dan Kalibrasi Sensor Gaya}

Sensor gaya yang digunakan dalam penelitian ini adalah load cell type $S$ (gambar 2) dengan kapasitas $500 \mathrm{Kg}$ dengan spesifikasi berturut turut ditampilkan dalam tabel 1,2, dan 3 . Load cell ini menggunakan 4 buah strain gauge dengan konfigurasi bridge, masing-masing strain gauge memiliki resistansi 350 ohm sehingga output impedansinya menjadi 350 ohm.

Tabel 1. Karakteristik sensor

\begin{tabular}{cc}
\hline Sensor Type & $\begin{array}{c}\text { Compression/Tension Load } \\
\text { Cell }\end{array}$ \\
\hline Weight Capacity & $500 \mathrm{~kg}$ \\
Max & $750 \mathrm{~kg}$ \\
Maximum Overload & \\
\hline
\end{tabular}

Tabel 2. Karakteristik elektris load cell Output Impedance $350 \Omega$ Supply Voltage Min 5 V DC Supply Voltage Max 12 V DC

Tabel 3. Karakteristik fisis load cell

\begin{tabular}{ll}
\hline Compensated Temperature Min & $-10^{\circ} \mathrm{C}$ \\
Compensated Temperature Max & $40^{\circ} \mathrm{C}$ \\
Operating Temperature Min & $-20^{\circ} \mathrm{C}$ \\
Operating Temperature Max & $55^{\circ} \mathrm{C}$ \\
Cable Length & $3 \mathrm{~m}$ \\
Cable Gauge & $5 \times 22$ AWG \\
Material & Alloy Steel \\
IP Rating & IP66 \\
Screw Thread Size & $\mathrm{M} 12$ \\
Weight & $603 \mathrm{~g}$ \\
\hline
\end{tabular}

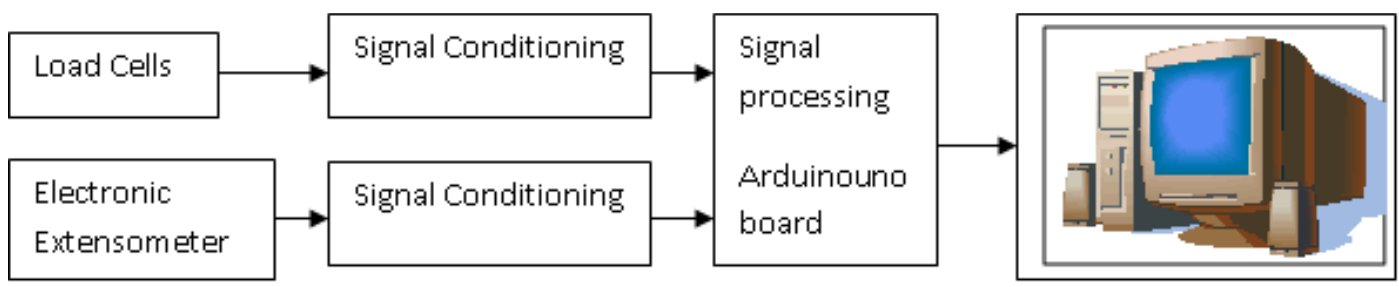

Gambar 1. Skematika diagram data akuisisi 


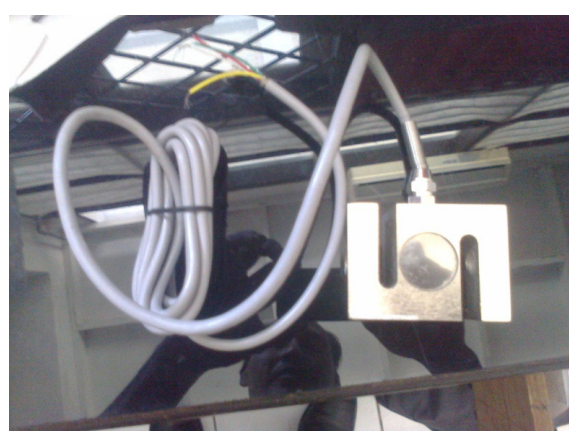

Gambar 2. Load cell tipe S

Tegangan kerja yang direkomendasikan adalah tegangan DC yaitu 5 volt sampai 12 volt, dengan data ini akan di rancang sebuah penguat operasional dengan tegangan kerja 5 volt dan komponen utama penguat oprasional ini adalah dari jenis IC AD620AN, merupakan penguat oprasional khusus untuk alat instrumentasi yang diproduksi oleh analog device. Fitur IC AD620AN ditampilkan dalam gambar 3 . Sedangkan gambar 4 menampilkan skema rangkaian penguat operasional yang dirancang untuk keperluan penguatan signal Load cell.

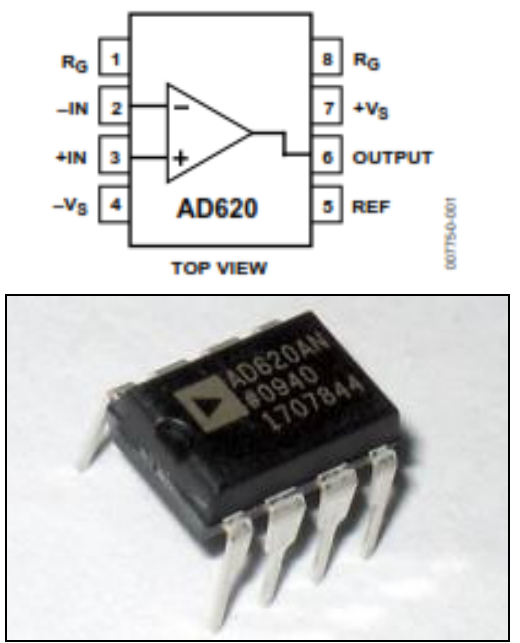

Gambar 3. Konfigurasi pin dan IC AD620AN

Rancangan penguat operasional ini terdiri dari dua tingkat penguatan (Gain) yaitu U1 digunakan untuk penguat pertama dan U3 untuk penguatan ke dua yang dilengkapi dengan rangkaian pengesetan nol untuk keluarannya. Masing-masing penguat dapat diatur penguatannya dengan mengatur ressistor variabel yang dipasang padanya yaitu RV1 dan RV2. Dari pengukuran langsung pada load cell didapat untuk setiap kenaikan beban $1 \mathrm{~kg}$ menghasilkan kenaikan tegangan output sebesar 0,01 mV. Load cell ini memiliki kapasitas beban sebesar $500 \mathrm{~kg}$ sehingga tegangan output saat ini sebesar 0,01 kali 500 yaitu $5 \mathrm{mV}$.

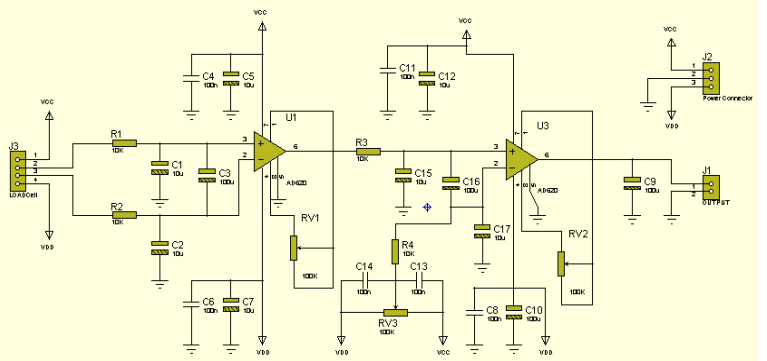

Gambar 4. Skematik diagram penguat oprasional

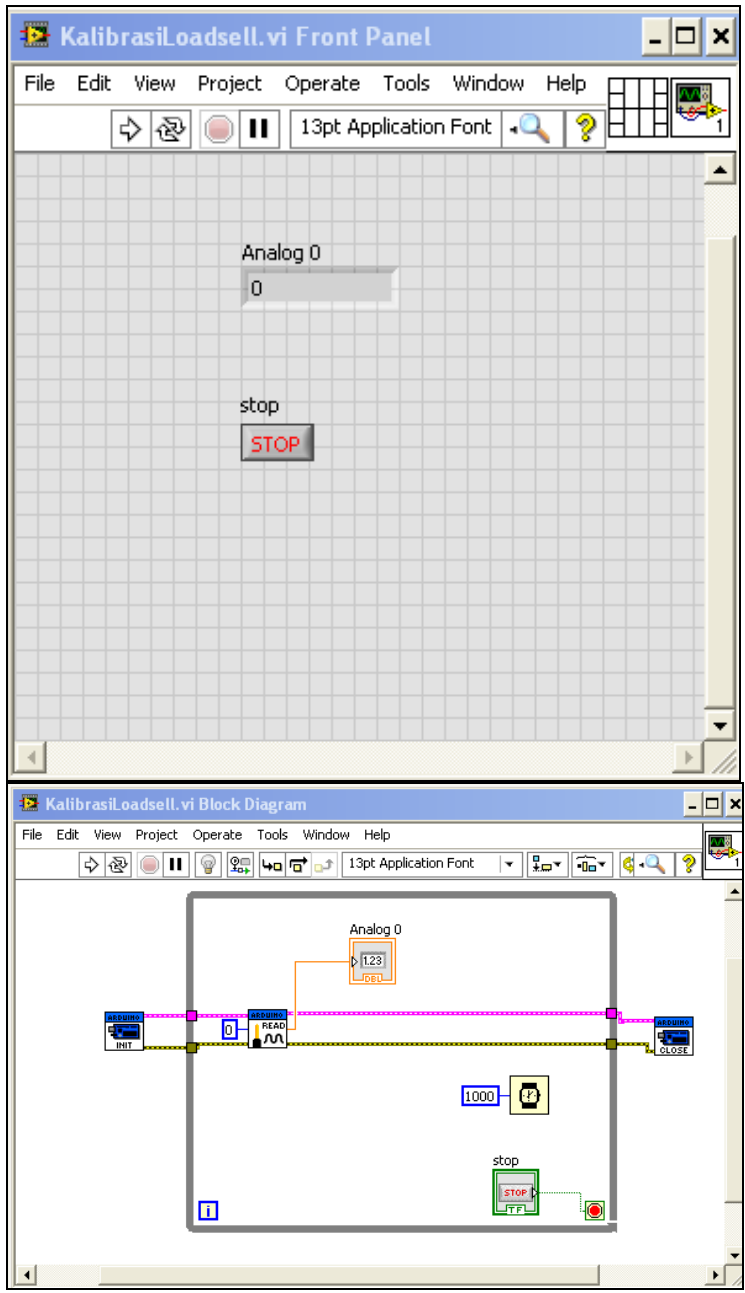

Gambar 5. Front panel dan block diagram

Akuisisi data pengukuran memiliki range input dari 0 sampai 5 volt, sehingga dibutuhkan penguatan (gain) sebesar 1000 kali. Untuk mendapatkan gain sebesar ini maka dilakukan seting pada penguat pertama dengan gain $\mathrm{A} 1=$ 100 dan gain penguat kedua $A 2=10$ sehingga gain total $A t=A 1 * A 2=100 * 10=1000$. 
Akuisisi data menggunakan ARDUINO UNO R3, dimana boad ini memiliki internal ADC 10 bit maka tingkat pembacaanya (akurasi) sebesar $=5 /$ $2^{\wedge} 10=5 / 1024=0,004883$ volt. Hal ini berarti perubahan angka digital 1 bit akan terjadi ketika perubahan voltase sebesar 0,004883 volt atau 4,883 $\mathrm{mV}$, jadi akusisi data dengan boad ini memiliki akurasi pembacaan $0,488 \mathrm{~kg}$, sehingga cukup layak digunakan untuk akuisisi alat uji tarik.

Pengaktifan Arduino board di perangkat lunak LabView menggunakan program LIFA_base. Adapun program Lab View yang digunakan untuk kalibrasi sensor gaya terlihat dalam gambar 5 .

Dari data hasil kalibrasi, tegangan awal yang terjadi sebesar 0,0342 volt.Selanjutnya, data V-koreksi dan pembacaan timbangan $(\mathrm{kg})$ ditampilkan dalam bentuk grafik untuk mencari persamaan korelasi antara kedua data tersebut, adapun grafiknya ditampilkan dalam gambar 5 .

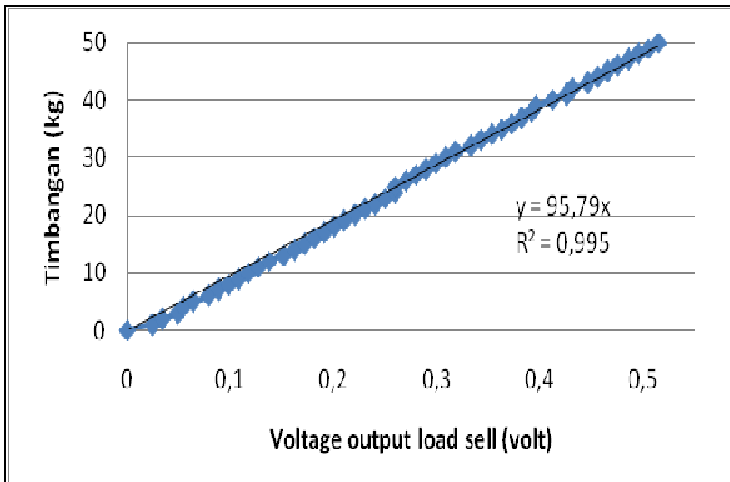

Gambar 6. Timbangan vs tegangan luaran load cell

Dari gambar 6, didapat persamaan trent line adalah $\mathrm{y}=95,79 \times$ dengan konfiden $\left(\mathrm{R}^{2}\right)=$ 0.995. Hal ini berarti keyakinan terhadap persamaan tersebut sebesar $99,5 \%$ atau kesalahan dari persamaan tersebut hanya sebesar $0,5 \%$.

\section{Perancangan dan Kalibrasi Elektronik Extenso meter}

Alat yang digunakan untuk mensensing pertambahan panjang spesimen uji tarik adalah menggunakan extenso meter yang mengikuti prinsif LVDT (Linear Variable Differential Transformer) (gambar 7). Sensor ini berfungsi untuk membaca pergerakan garis lurus secara linear.Gambar 6 menampilkan skematik diagram signal generator menggunakan IC LM555CN

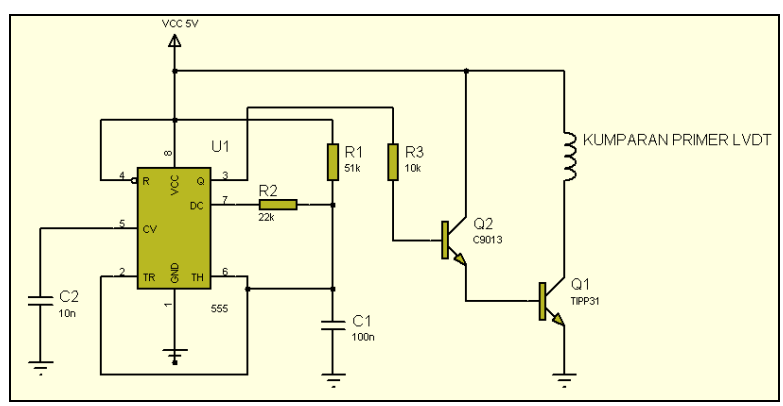

Gambar 6. Skematik signal generator IC LM555CN

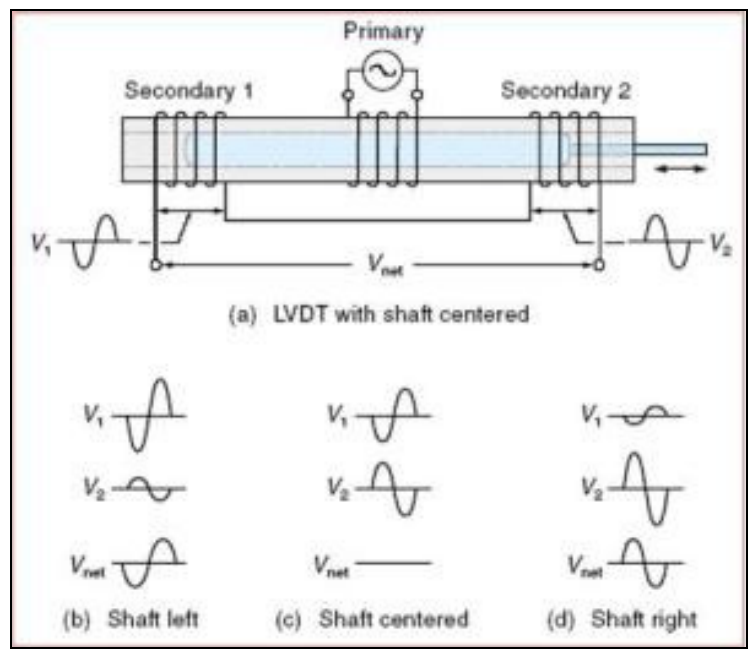

Gambar7. Skema LVDT

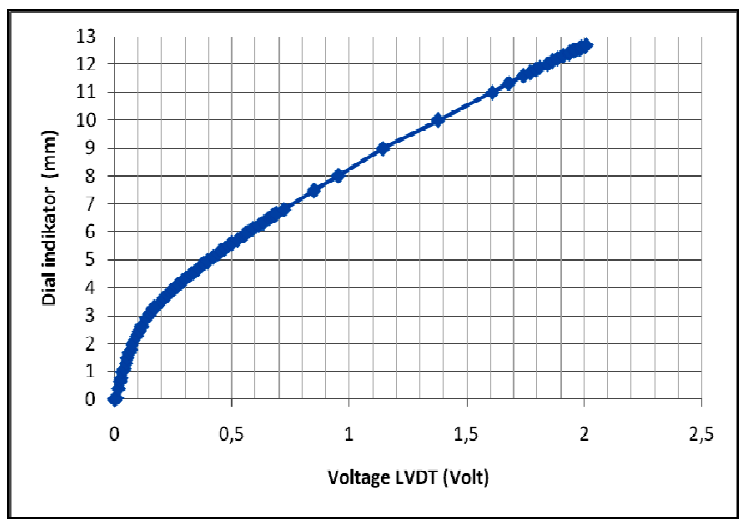

Gambar 8. Tegangan luaran LVDT vs dial indicator

Data hasil pembacaan LVDT tidak sama dengan nol, sehingga perlu diinisialisaisi. Hasil inisialisaisi tersebut menghasilkan data sebesar 0,336914 volt. Selanjutnya data ditampilkan dalam bentuk grafik, seperti terlihat dalam gambar 8 . 
Pada gambar 8 terlihat bahwa daerah linier dimulai dari voltase LVDT $=0,302734$ volt dan pembacaan diel indicator $=4,322 \mathrm{~mm}$. Dari hal ini diketahui daerah kerja LVDT yaitu diatas voltase output 0,302734 volt. Linierisasi dari luaran LVDT ditampilkan dalam gambar 9 .

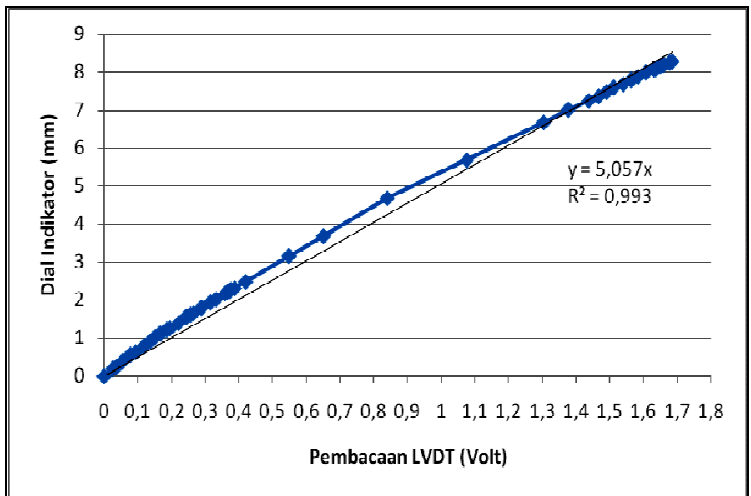

Gambar 9. Linierisasi daerah kerja LVDT

Dari gambar 9 terlihat bahwa persamaan liniernya adalah $\mathrm{y}=5,057 \mathrm{x}$ dengan tingkat konfiden $99,3 \%$ atau hanya $0,7 \%$ persamaan tersebut menyimpang pada penentuan pertambahan panjang dari voltase output yang dihasilkan oleh LVDT. Akurasi pembacaan perpanjangan dapat dihitung dengan mengetahui perubahan angka digital 1 bit untuk arduino board adalah 0,004884 volt, sedangkan dari data pengukuran dengan LVDT yaitu 0,191 mm menunjukan 0,024414 volt. Akurasi pembacaan perpanjangan $=(0,004883 / 0,024414) \times 0,191 \mathrm{~mm}$ $=0,038 \mathrm{~mm}$.

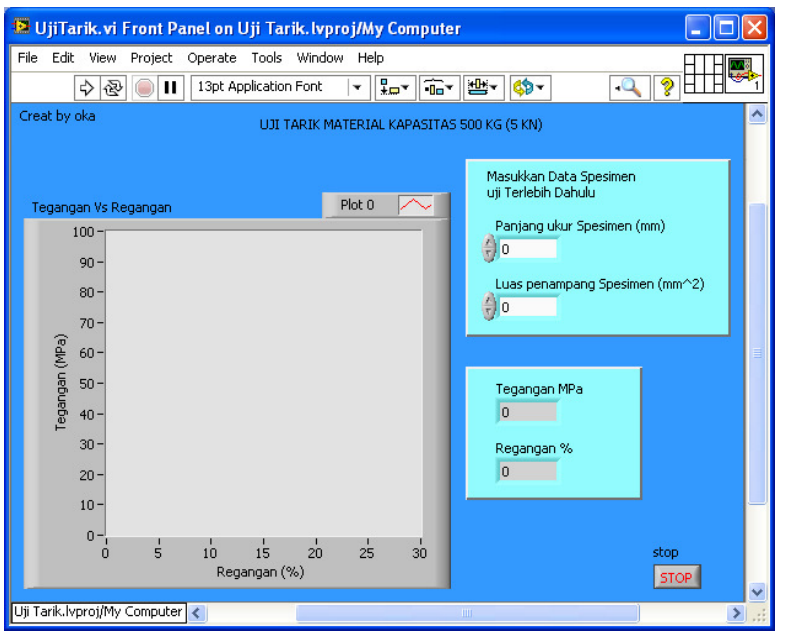

Gambar 10. Front pane/ perangkat lunak ujin tarik

$$
\begin{aligned}
& \text { Persamaan linier untuk sensor gaya dan } \\
& \text { sensor pertambahan panjang selanjutnya }
\end{aligned}
$$

digunakan dalam pemprograman. Selanjutnya, data akuisisi yang dikembangkan dengan perangkat lunak Labview ditampilkan gambar 10 .

\section{KESIMPULAN}

Pada perancangan data akuisisi menggunakan sensor load sell dan LVDT dapat disimpulkan sebagai berikut: Arduinouno R3 memiliki akurasi pembacaan sebesar $0,488 \mathrm{~kg}$ dan $0,038 \mathrm{~mm}$. Persamaan kalibrasi gaya adalah $\mathrm{y}=$ 95,79 x. Persamaan kalibrasi perpanjangan adalah $y=5,057 x$. Program labview dapat digunakan untuk data logging uji tarik.

\section{DAFTAR PUSTAKA}

Callister W.D., 2007, Material science and engineering; Introduction, 6ed, John Wiley and Sons, Inc., New York.

Dean N., Adjei J., Moreno S., Nicknish S., 2014, Design, development and manufacturing of a micro-tensile tester for in situ afm/optical microscopy applications, micromechanica material testing systems, Department of Mechanical Engineering, The University of Texas, Dallas.

Lim W., Kim H.K., 2013, Design and development of a miniaturised tensile testing machine, Global Journal of Engineering Education, 15(1), 48-53. 